\title{
The Management of Safety in Schools in The State of Perak, Malaysia
}

\author{
Nek Kamal Yeop Yunus ${ }^{\mathrm{a}}$, Tirzah Zubeidah Zachariah ${ }^{\mathrm{b}}$, Ahmad Amri Zainal Adnan ${ }^{\mathrm{c}}$ \\ ${ }^{a}$ Faculty of Management and Economic, Sultan Idris Education University, Malaysia, \\ nkamal@fpe.upsi.edu.my \\ ${ }^{b}$ Faculti of Education and Social Sciences, Universiti Industri Selangor, Malaysia, ztirzah@yahoo.com \\ ${ }^{c}$ Faculty of Management and Economic, Sultan Idris Education University, Malaysia, \\ a.amri@fpe.upsi.edu.my
}

\begin{abstract}
This study was conducted to ascertain the management of safety in secondary schools located in the Northern Kinta District, Perak. The aspects of school safety studied were social dimension and physical dimension. This study was also conducted to find out whether a significant relationship existed between the social dimension and physical dimension towards school safety. The study sample consisted of teachers who had undergone the Higher Order Thinking Skills (KBAT) Course for Lower Secondary and a questionnaire was utilised as the study instrument. The data collected was then analysed to ascertain the practices, effects, limitations and findings from the school safety management programme which had been conducted for 11 years. The data was analysed using the Statistical Package for Social Sciences (SPSS) Version 20.0 and also using descriptive analysis in the form of percentages and frequencies. The findings showed that 6 factors had a significant co-relational relationship (Truancy, Fights, Classroom safety, Workshop safety, Laboratory Safety and Fire Safety) and only two factors were not significant (Bullying and Co-curriculum activities safety). The R2 value was moderate at .482 which showed that the $48.2 \%$ change in school safety was due to the eight independent variables. This showed that there was a significant relationship between the social dimension and physical dimension. As such, the study findings showed that the safety practices were important in influencing the study environment at school especially for the students as they needed to feel safe from any disruption or risks of accident.
\end{abstract}

\section{Keywords:}

Education, Malaysia, safety management, school safety

\section{INTRODUCTION}

A safe school is a place where students can study and teachers can teach in a comfortable environment free from any harm. It is also a place where the study environment can promote an acceptance of vigour and protection among the students (Neal \& Griffin, 1998). Neil defines a safe school as a calm place where the students and teachers are free to learn and teach without any physical and social harms. The key to a safe school is one with an environment which emphasises friendliness, a caring attitude, with clear guidelines on appropriate behaviour and the school itself should be continuously fair towards the students (Griffin, 2002).

The Malaysian Ministry of Education (2011) refers a safe school as a place which is always safe and free from unwanted incidents such as pupils being threatened, kidnapped, raped, getting involved in drugs or in gangster or triad society activities. The members of such an institution need protection and security. The issues of health and security in a school should cover matters related to safe buildings, constructed structures, toilets, classrooms, offices, laboratories and also school co-curricular activities. 
Schools' adherence to the 1994 Occupational Safety and Health Act aims to make the places safe and healthy for teachers, students and visitors as well as parents (Lee Lam Thye, 2017). Lee Lam Thye also said, according to the Malaysia's National Institute of Occupational Safety and Health (NIOSH), the 'Safe School Campaign' should not be limited to aspects of school safety, equipment and facilities. Schools should also be aware of the existence and importance of the 1994 Occupational Safety and Health Act and its implications to the educational institutions. It's Chairman stressed that the act aims to protect employees such as teachers and other staff as well as other parties such as students, teachers and community members.

The safety aspects cover the physical structure, traffic, food, building, field, health, discipline and behavior (Shamsiah Mohd Amin \& Said Hamdan, 2009). Based on this, the Malaysian Ministry of Education established the 'Safe School Policy' to be implemented in all schools. Parents, schools and the community should be responsible and cooperate to ensure the effectiveness of this policy and not just blame each other when an incident happens. As such, the school management and the education department which represent the employer are responsible for ensuring the safety and welfare of teachers, support staff and the students. In the school institution, employees are the teachers, administration and support staff, while students are considered as others.

This study aims to achieve its objectives which are to ascertain whether truancy, bullying, getting involved in fights, aspects of class, workshop, laboratory, fire hazard and security influence the safety of the school. It also aims to ascertain the contributions of the social and physical dimensions towards school safety.

\section{REVIEW OF LITERATURE}

According to Brierly (2011), the success of a school is measured through its capability to provide the best education to its student. A school is considered the best school if its public examination results are better than those from other schools. However, safe school environment and physical facilities also play a role to ensure a school's success. This shows that safety issues also have a direct effect on the success of a school.

The school should focus on the safety issues as the number of students increase every year due to the general public's improving level of knowledge, health and economy. The increase in the number of students provides an implication towards the school management's capability to ensure that students are free from accident risks. The students are exposed to injury risks due to accident not just in the classroom but also during their co-curricular activities. This causes the school authority (especially teachers) to be fully responsible for the students during the schooling hours (Blauvelt, 2009).

A few accidents had occurred in schools involving students, such as one particular case when a boy scout died after a pulley fell on his head (Berita Harian, 9th Jan 2011), another case when a Mechanical Engineering student at a technical school was reported to have had his left kidney removed after being beaten by senior students (Asmah Subuh, Nurulhuda Azizi \& Mascilla binti Hamzah, 2011), and an eleven years old student of primary school suffered a bruised eye and a swollen face after he had fallen into an uncovered drain at school (Utusan Malaysia, 9th Feb 2014). These are some of the cases which can make us aware of the unexpected risks at school. Furthermore, some of the schools' dilapidated physical condition can bring harm to the students. 
According to Xiao Lini and Ma Yingnan (2010), some schools were considered to be unsafe in terms of the physical aspect due to the structure of the buildings and the locations which are not conducive for the teaching and learning process. Some 600 secondary and primary schools in a state in Malaysia which were built in the 1980s are considered dilapidated and this may harm the lives of students and teachers.

As stated by Sharifah Md Nor (2000), a few incidents which occurred at secondary schools and residential schools had resulted in injuries ranging from minor to death-causing ones. These incidents should not be taken lightly as not all of them originated from the school itself. The school is only a venue for the occurrences and when the safety aspects are not focused on, many unwanted incidents can happen. As similar incidents have happened a few times, the issue of students' safety does raise a few questions.

The safety aspect should be focused on and an in-depth understanding may help teachers to avoid any unwanted incidents and also decrease the risk of being prosecuted by the parents and students. This is because today's parents and students are more aware of rules and regulations, which enable them to take legal action if something bad happened to their children. The school is not safe enough if the regulatory and legal aspects are not seriously considered (Salleh Buang, 2005).

\section{The safe school concept}

This concept had been introduced by the Ministry of Education in order to create a school environment free from danger as well as internal and external harm. Based on the 2002 Safe School Concept Manual, there are 5 areas of safety in school which are natural disaster, students' activity, social, school building and physical aspect as well as school location and environment. In this study, the focus would be on the social and physical dimension.

\section{Brookover Student Academic Climate Theory and the Reynolds Effective School Theory}

This study utilised the Brookover Student Academic Climate Theory (1979), the Reynolds Effective School Theory (1976) and also studies from Mortimore et al. (1988). Safety plays a major role in the school's academic climate. Apart from the school academic climate, school safety is also influenced by social input such as bullying, truancy, vandalism, gangsterism, fighting and other social problems. In fact, the physical and economic aspects also affect school safety. Five factors influence school safety which arehumans, location, policy, program and process. According to the theories in this study, the school safety is implemented at school and conducted by the administrators such as the principal and based on the policies outlined by the Malaysian government. A healthy school is a school which exists in a specific environment for an extended period and is successful in managing any pressures from inside and outside, It is also a school which is effective in using available resources to ensure that the occupants are always in a safe environment and they are able to solve any problems or conflicts related to the safety of the school.

The first and most valuable factor involves humans; these would be the administrators, teachers, students and school community who play an important role inschool safety. The second factor is location. Places such as classroom, laboratory, workshop, canteen, staffroom, corridor and other places at school have a direct effect on school safety. If these places are not monitored, they may be the source of negative effects such as discomfort and accident risks. 
The third factor is policy. School safety is based on the policy or regulations stipulated by the government. These regulations provide an effective for school administrators in implementing the safe school policy. Furthermore, the policy provides useful information about important personnel, management skills and responsibilities. The fourth factor is programme. The implementation of a safe school is effective with the planned programmes which involve all members of the school community and it also functions to cultivate responsibility related to school safety among the community members.

The fifth factor is process. This is an element which makes school safety more effective. This is because the principal is able to attract the attention of teachers and the school community to cooperate in every aspect, The process involves unity, democracy, cooperative effort and responsibility.

\section{The social dimension of school safety}

We often talk about the various behavioural problems plaguing youngsters these days. Most people would probably point fingers at the youngsters and accuse them of planning their lives wrongly. A few problems come to mind such as 'mat rempit', drugs, vandalism and promiscuity.Actually, not all the behavioural problems are entirely caused by the students. By understanding students who have disciplinary problems, behaviour shaping can be implemented.

Azizi Yahaya and Norfaizah Majid (2010) found that truancy was one of the aspects which influenced school safety. The authors reiterated that school safety was also influenced by social aspect. Furthermore, a study by Asma Nabihah (2014) discovered that truancy was an uncontrollable disturbance which would affect the safety of a school, especially to the students. On the other hand, Abdullah Sani Yahaya (2004) found thattruancy did not affect the safety of the school as it was caused by the students' behaviour and pressure from the students' peers as well as pressures from outside the school. Another study by Yusof Boon and Jamaluddin Ramli (2008) discovered that the school was a place where bullying often happened; bullying instances also happened during recess time, during the trip to school and from school to home. This was in line with findings from Olweus and Limber (2009) which stated that the classroom was a place where bullying often occurred, as reported. This was also parallel with findings from Borg et al. (1999) which informed that the school field and classroom were locations where bullying frequently happened; other bullying instances also happened during the trip from school to home as well as while the students were walking through the school corridor. All these indicated that bullying had an effect on school safety.

According to Asmah Suboh et al. (2011), students getting into fights was a relatively low phenomenon as only 3.1 percent of the study respondents were involved in high-level fighting. On the other hand, Charach, Pepler and Ziegler (2015) warned that the school authorities might see this type of fighting as not so harmful and should not be focused upon, unless it has encroached on several boundaries to the extent that a person is physically harmed. These findings indicated that fighting influenced school safety, especially the students.

Problematic or undisciplined behaviour can be prevented; the student can then be encouraged to practise good behaviour (Alberto \& Troutman, 2010). By assuming that all behaviour can be cultivated, the teacher plays an important role to assist students who have behavioural problems to build a positive attitude so that they can be accepted at school. Another theory which utilises the behavioural approach is the Social Learning Theory put 
forward by Albert Bandura. According to Bandura (2012) a person acts based on his or her experience by looking at other people whom he/she considers as models. He or she will keep on practising what he sees as behaviour that needs to be emulated. If this is done continuously, the behaviour will remain within the individual. This means that the teacher has to become a role model and the best example for his or her students. Teachers have to be vigilant of what is happening in the school compound or in the classroom. Students with good behaviour should be encouraged to maintain their positive demeanour.

\section{The physical dimension of school Safety}

A good school environment can influence the safety of students. A study report on safe schools in America by (Friedfel \& Haenn, 2012) found a connection between school size and vandalism. A crowded school or one with too many students would be difficult to control and this would give rise to lots of problems. Another study reported a significant relationship between school environment (Earttman \& Lenmaster, 2004). In a study related to the effect of school factors on students' learning as reported by David (2010), 83 percent of the 658 respondents (who were American security enforcement officers) stated that the school was a place easily infiltrated by outsiders, $55 \%$ stated that the school plan was not adequate enough to handle any crisis and 52\% stated that the school plan had never been tested before. A few safety aspects should be prioritised by the teachers as well as the school authorities to maintain the safety in the school. Some of them include ensuring the safety during class periods while conducting practical and craftsmanship work (for subjects like Living Skills, Agricultural Science, Technical and Vocational, Domestic Science and Music) and also the safety of the school's physical structure, safety during co-curriculum activities, safety of sports facilities, safety during outings and visits, traffic safety in the school area and also safety from fire.

\section{Ensuring safety during classes}

According to the School Safety Act 1994, the teacher has to conduct a reasonable supervision for students under his or her care during the class. Failure to do so may result in the cause teachers being charged if the student is injured due to former's negligence.

Occupational Safety and Health Act 1994 reported that a student was injured when his friend pierced his thigh with a pin, causing him to react by turning backwards and further causing his eye to be poked with a sharp pencil. Meanwhile, the teacher was doing his own work after asking the students to do the exercises in their book. At that time, without being seen by the teacher, the plaintiff had moved and poked another student who had previously sat beside the latter. The High Court investigations found that the teacher had acted carelessly by not supervising in a reasonable manner thus causing the student to lose one eye. However, an the appeal had been submitted by the defendant in the Federal Court and later accepted on two grounds: (1) The injury suffered by the plaintiff was a type of injury which could not be predicted reasonably as the teacher did not expose the student to the injury; and (2) continuous monitoring could not guarantee that such an injury would not happen.

As such, the teacher should monitor the students' safety all through the teaching and learning process as long as the students are in the school compound. This is because the school and the teachers play the roles of good and reasonable parents or to use the term 'in loco parentis' to describe the roles and responsibilities (Tai Fatt Hee, 2004). 


\section{RESEARCH METHODOLOGY}

The research utilised a quantitative research model which focused on the survey method to collect data about the population based on the chosen study sample. In the case of this study, the survey had been constructed based on the Safe School Guidebook published by the Malaysian Ministry of Education (2002). The survey contained 52 item and divided into 4 parts. Cronbach Alpha for the dimension (Social, Physical and School Safety) range between .73 to .79 .

The respondents were teachers from 31 secondary schools in one of the northern state of Malaysia. The population numbered 2401 teachers in secondary schools and the data was acquired from the Kinta District Education Office. 350 questionnaires were distributed to the teachers. However, the questionnaire return rate was low as only 150 questionnaires were returned out of the 350 distributed questionnaires. This indicated that only 43 percent of the teachers responded.

In this study, the researchers utilised 2 statistical methods to analyse data. The first method was the descriptive method which involves thestatistical method used to find the frequency and percentage to analyse the demographic factors of the respondents. According to Umar Sekaran (2012), based on the research findings, a few variables under study can be explained based on factors such as frequency distribution to find the answer for every question, changing the answers into percentages, finding the average and so on. The second method was using the inference method to analyse the study hypotheses. The researchers used correlation to analyse the 8 hypotheses and whether they had a significant relationship or otherwise. After that, regression was used to find the contribution of dependent variables towards independent variables in this study.

\section{RESULTS}

The data acquired was analysed using descriptive analysis and inferential analysis (involving correlation and regressive analysis). The majority of respondents were teachers aged between 36-40 years (30\%), 106 female teachers $(70.7 \%)$, 95 teachers were from the Malay ethnic group and followed the Muslim faith Islam religion (63.3\%), 98 are married and had at least a Bachelor's degree (65.3\%). For further details, please refer to Table 1.

Table 1: Frequency and demographics percentage

\begin{tabular}{lcc}
\hline Respondents demographics & Frequency & Percentage \\
\hline Age (year) & $36-40$ & 30 \\
Gender (female) & 106 & 70.7 \\
Ethnic group (Malay) & 95 & 63.3 \\
Religion (Islam) & 95 & 63.3 \\
Status (Married) & 104 & 69.3 \\
Academic qualifications (Bachelor's degree) & 98 & 65.3 \\
\hline
\end{tabular}

The regression test was used to find the variable which strongly affected the safety of the school. The test results could be seen by the absence of significant contribution by social dimensions and physical dimensions to school safety. 
Based on Table 3, the correlation between dependent variables was .695 or $69.5 \%$. The $\mathrm{R}^{2}$ value at 0.482 showed that the $48.2 \%$ change in dependent variable school safety criterion variable was caused by the combination change between the eight variables. The adjusted $\mathrm{R}$ square showed the strength of the relationship between the eight independent variables. The adjusted $\mathrm{R}$ square for all variables was .453 . This mean that $45.3 \%$ of the variation could be explained using this model. The remaining $54.7 \%$ consisted of errors or other variables (were) not described by this study. This was due to other factors beyond the researchers'study.

Table 2: Matrix Correlation of all dependent variables and school safety

\begin{tabular}{lll}
\hline Dimension & Significance & School Safety \\
\hline Truancy & .002 & $.239 * *$ \\
Bullying & .080 & -.115 \\
Fighting & .000 & $.310 * *$ \\
Class safety & .000 & $.417 * *$ \\
Workshop safety & .010 & $-.189^{*}$ \\
Lab safety & .000 & $.421^{* *}$ \\
Fire safety & .004 & $.217^{* *}$ \\
Co-curriculum activity safety & .108 & .102 \\
& & \\
$* *$ correlation was significant at level of 0.01 (two-tailed) \\
$*$ Correlation was significant at level of 0.05 (one-tailed) \\
$\mathrm{n}=150$
\end{tabular}

Table 3. Regression model results

\begin{tabular}{|c|c|c|c|c|}
\hline Model & $\mathrm{R}$ & R Square & $\begin{array}{l}\text { Adjusted } \\
\text { R Square }\end{array}$ & $\begin{array}{l}\text { Std. Error of the } \\
\text { Estimate }\end{array}$ \\
\hline 1 & $.695 a$ & .482 & .453 & .0789 \\
\hline
\end{tabular}

The data analysis showed that the $\mathrm{R}^{2}$ value was at a medium level at .482 ; this showed that the $48.2 \%$ change in school safety was caused by the eight variables :truancy, bullying, fighting,class safety,workshop safety, lab safety, fire safety and co-curriculum activity safety. A linear combination of the eight independent variables contributed $48.2 \%$ of variance for the dependent variable.

The findings of the analysis showed that classroom safety was the most influential predictor variable compared to other predictor variable in influencing school safety with the value of $\beta=.790$. Table 4 showed that a change in classroom safety of $1 \%$ would influence the school safety about $79.0 \%$. As such, there existed a significant relationship between school safety and classroom safety at the significant level $p=.00$ when $p<.05$. This indicate that classroom safety was the most dominant social dimension or the biggest contributor towards school safety compared to other variables. Additionally, the second highest predictor variable influencing school safety was fighting with $\beta$ value $=.779$. This indicated that a change in fighting of $1 \%$ would influence school safety about $77.9 \%$. As such, there existed a significant relationship between school safety and fighting at the significant level $\mathrm{p}=.00$ 
when $\mathrm{p}<.05$. Furthermore, the lowest predictor variable influencing school safety was truancy with the value of $\beta=.002$. This showed that a change in truancy of $1 \%$ would influence the school safety about $0.2 \%$. Therefore, there was no significant relationship between school safety and truancy at the significant level $p=.99$ when $p<.05$. However, other predictor variables aslo had a significant relationship but did not contribute much to the change in school safety as the combination for predictor variable for bullying was $(\beta=-.440$, $\mathrm{p}<.05)$, laboratory safety was $(\beta=.382, \mathrm{p}<.05)$, workshop safety was $(\beta=-.274, \mathrm{p}<.05)$, fire safety was $(\beta=.289, \mathrm{p}<.05)$ and co-curriculum activity safety $\operatorname{was}(\beta=-.194, \mathrm{p}<.05)$.

As such, the findings showed that the physical dimensionwith factors such as classroom safety, laboratory safety and safety from fire had significant contribution compared to workshop safety and co-curriculum activity safety, which did not contribute towards school safety. For social dimension, the truancy factor did not contribute towards school safety but the bullying and fighting factor had significant contribution towards school safety. This showed that there was significant contribution from the social dimension and physical dimension towards school safety although one factor in social dimension and two factors in physical dimension did not contribute towards school safety.

The regression analysis was also used to identify which factor influenced school safety the most. The $\mathrm{p}$ value acquired would be used to identify whether the hypothesis was accepted or otherwise. The hypothesis would be accepted if $p<.05$. The overall findings indicated that there was significant contribution from the physical dimension and social dimension towards school safety; however, it was also discovered that one factor in social dimension and two factors in physical dimension did not contribute towards school safety.

\section{DISCUSSION}

There were two dimensions to be focused on in this study which were assumed to affect school safety. The two dimensions were the social dimension (truancy, bullying and fighting) and the physical dimension (classroom, laboratory, workshop, fire, co-curriculum activities). The findings were supported by previous studies which had been reported by other researchers. The findings are reported below :

There is no significant relationship between truancy and school safety. There was a significant correlational relationship which indicated a direct relationship between truancy and school safety and the correlational relationship was at a low level as the correlation coefficient showed $r=.239$. According to Azizi Yahaya, Shahrin Hashim, Jamaluddin Ramli, Yusof Boon and Abdul Rahim Hamdan (2007) truancy was one of the aspects which influenced school safety. The authors stressed that the school safety was also influenced by social aspect. Additionally, a study by Asma Nabihah (2014) found that truancy was an uncontrollable disturbance and would affect the safety of a school especially to the students. However, according to Abdullah Sani Yahaya (2004), truancy did not affect the safety of the school as it was caused by the students' behaviour and pressure from the students' peers as well as pressures from outside the school.

There is no significant relationship between bullying and school safety. There was a negative correlational relationship between bullying and school safety which indicated an inverse relationship between bullying and school safety as the correlation coefficient showed $r$ $=-.115$. However, a study by Yusof Boon and Jamaluddin Ramli (2008) found that the school was a location where bullying often occurred; other bullying instances happened during recess time, during the trip to school and from school to home. This was parallel with findings from Olweus and Limber (2009) which stated that the classroom was a location where bullying 
often occurred, as reported. This was also in line with findings from Borg (1999) which informed that the school field and classroom were locations where bullying frequently happened; other bullying instances also happened during the trip from school to home as well as while the students were walking through the school corridor. This showed that bullying had an effect on school safety.

There is no significant relationship between fighting and school safety. There was a significant correlational relationship which indicated a direct relationship between fighting and school safety and the correlational relationship was at a low level as the correlation coefficient showed $r=.310$. As stated by Asmah Suboh et al. (2011), this type of student misconduct was at a low level as 3.1 percent of the respondents were involved in high-level fighting. However, according to Charach et al. (2015), the school authorities might see this type of fighting as not so harmful and should not be focused upon unless it has encroached on several boundaries to the extent that one is physically harmed. This proved that fighting influenced school safety, especially the students.

There is no significant relationship between classroom and school safety. There was a significant correlational relationship which indicated a direct relationship between classroom safety and school safety and the relationship was at a medium level as the coefficient correlation showed $r=.417$. The null hypothesis was successfully rejected as $p=.000$ when $\mathrm{p}<.01$ According to Aziz Yahya et al. (2007), the school should provide a safe physical environment and this is especially pertinent when there is a need for building safety audit specifically when it concerns the classroom, decreasing the classroom size and conducting supervision in the classroom from time to time. This is because the classroom is a place where the students learn and there is a requirement for safety.

There is no significant relationship between workshop and school safety. There was a negative correlational relationship which showed an inverse relationship between workshop safety and school safety and the correlation coefficient showed $r=-.189$. According to Mohd Tarmizi Mohd Zabidi (2007), the safety aspect is extremely important and should be focused on while doing practical work in the workshop. This is because the students are exposed to the machinery when they are in the workshop. Additionally, a study from the Halpin and Croft (2013) showed that workshop safety can be increased when the equipment in the workshop is properly maintained from time to time.This indicated that workshop safety influenced school safety.

There is no significant relationship between laboratory and school safety. There was a significant correlational relationship which indicated a direct relationship between laboratory safety and school safety and the correlation relationship was at a moderate level with the correlation coefficient showing $r=.421$. According to Meor Ibrahim Kamarudin et al. (2010), safety should be practised in the laboratory and while the experiments are ongoing. Halimaton and Zaiton (2014) also stated that all parties involved in laboratory matters should ensure the safety of the individual, workplace, environment as well as other people working in that location. Science teachers and laboratory assistants should be aware and understand as well as practise the safety regulations in the laboratory to secure their safety.

There is no significant relationship between safety from fire and school safety. There was a significant correlational relationship which indicated a direct relationship between safety from fire and school safety and the correlation relationship was at a low level with the correlation coefficient showing $\mathrm{r}=.217$. As such, the null hypothesis was successfully rejected as $\mathrm{p}=.004$ when $\mathrm{p}<.01$. The null hypothesis was successfully rejected and this showed that there was a significant relationship between safety from fire and school safety. Statistics from the Malaysian Statistic Department (2013) showed that a majority of fires 
occurred at school especially in laboratories and workshops. As stated by Tang Hing Kwong (2002), the school authorities should provide fire protection for the entire school area and also expose the students on how to overcome small fires.

There is no significant relationship between co-curriculum activities and school safety. There was a significant correlational relationship which indicated a direct relationship between co-curriculum activities and school safety as the correlation coefficient showed $\mathrm{r}$ $=.102$ which was a very weak relationship. According to Ang (2007), safety during cocurriculum activities provides confidence to the students to participate in the activities without any harm. The students would not be exposed to any accident risks if their safety is prioritised. According to Fuller (2009), injuries during co-curriculum activities are common in schools and this results from a lack of knowledge and experience from all parties involved such as the school administration as well as teachers and coaches.

There is no significant contribution from social dimension and physical dimension towards school safety. The correlation between the dependent variables was .695 indicating $69.5 \%$. The $\mathrm{R}^{2}$ value was .482 and this indicated a $48.2 \%$ change in the variable criteria for school safety dependent variable due to the combination change between the eight variables. The data analysis findings showed that the $\mathrm{R}^{2}$ value was at a moderate level at .482 indicating a $48.2 \%$ change in school safety and this was caused by changes in the eight independent variables: truancy, bullying, fighting, class safety, workshop safety, laboratory safety, safety from fire and co-curriculum activity safety. The linear combination of the eight independent variables contributed a 48.2 variance towards the dependent variables.

As stated by Mohd Salleh Lebar (1997), a safe school is a place where students can study and teachers can teach in a comfortable environment free fromany harm. Furthermore, according to Halpin and Croft (2013) a safe school is a school which strives to ensure that its occupants are free from any physical, mental, emotional or psychological danger or harm which could affect the effectiveness of the teaching and learning process at school.The safety aspect covers aspects such as the physical structure, traffic, food, building, field, discipline and behaviour. This indicates that the social and physical dimension influenced the safety of the school. As such, we can conclude that the findings of this study were in line with the findings from previous studies. The social and physical dimension were able to influence the safety of the school and would cause accidents or injuries if the safety aspect is not given top priority.

\section{CONCLUSION}

Based on the study conducted, social dimension proved to be a dominant factor which influenced school safety. This was due to aspects such as truancy, bullying and getting into fights, which all influenced the school safety. As such, a more comprehensive approach should be planned to identify the level of school safety practices and the factors involved. The findings indicated that teacher involvement, especially at school, was very high in implementing the school safety policy. However, this was limited to the social and physical dimension as required by the researchers. As such, to ensure that Vision 2020 is achieved in line with the government's aspirations, it is imperative that each party plays its role in the effort to implement the MOE's mandate of managing the safety and security of the school. 


\section{References}

Abdullah Sani Yahaya. 2004. Mengurus Disiplin Pelajar. Pahang Darul Makmur: PTS Publications \& Distributors Sdn. Bhd.

Ang, K. K. 2007. Kompetensi Setiausaha Sukan Dan Amalan Pengurusan Risiko Dan Keselamatan Program Sukan Sekolah Menengah Di Malaysia. Unpublished PhD Thesis, Universiti Putra Malaysia, Selangor.

Azizi Yahya \& Nurfaizah Majid. 2010. Pelbagai Aspek Budaya Formal di Sekolah. Johor: Penerbit Universiti Teknologi Malaysia.

Azizi Yahaya, Shahrin Hashim, Jamaluddin Ramli, Yusof Boon \& Abdul Rahim Hamdan. 2007. Menguasai Penyelidikan dalam Pendidikan. Kuala Lumpur: PTS Professional publishing Sdn Bhd.

Asma Nabihah Abd. Rahman. 2014. Faktor-Faktor Yang Mendorong Pelajar Felda Ponteng Sekolah: Satu Kajian Di Sekolah Menengah Air Tawar, Kota Tinggi, Johor. Unpublished Diss., Universiti Teknologi Malaysia, Skudai, Johor.

Asmah Suboh, Nurulhuda Azizi \& Mascilla binti Hamzah. 2011. Masalah Salah Laku Agresif Di Kalangan Pelajar Sekolah Rendah Dan Hubungannya Dengan Gaya Keibubapaan Sekolah Menengah Kampung Baru, N.Sembilan. Journal of Education Psychology \& Counseling 1(3): 77-93.

Alberto, P. A. \& Troutman, A. C. 2010. Applied Behavior Analysis for Teachers at University of Virginia. Toronto: Merril Pub Co.

Bandura, A. 2012. Bandura's Social Learning Theory \& Social Cognitive Learning Theory. Iowa: University of Science \& Culture Press.

Blauvert, P. D. 2009. Making School Safe for Students. USA: SAGE Publications Ltd.

Borg, M. G. 1999. The Extent and Nature of Bullying Among Primary and Secondary School Children. Educational Research 1(41):137-153.

Brierley, D. 2011. Health and Safety In School. London: Paul Chapman Publishing Ltd.

Charach, A., Pepler, D. J. \& Ziegler, S. 2015. Bullying at School: A Canadian Perspective. Education Canada 35(1):12-18.

David, D. 2010. What Teachers Need to Know: The Knowledge, The Skills, and Values Essential to Good Teachings. San Francisco: Jossey Bass Publisher.

Eartman, C. \& Lensmasters, D. 2002. Dimensions of School Organization and Student Academic Achievement. Baltimore: Uniuversity of Maryland Press.

Friedfel, J. \& Haenn, B. 2012. Class Size and Student Success: Comparing the Results of Five Elementary Schools Using Small Class Sizes. Paper presented at the Annual Meeting of the American Educational Research Association, 1-5 April, New Orleans, LA.

Fuller, C.W. 1999. Safety in Sport : Guidance for UK National Governing Bodies. Available 
at http://www.healthsport.eu/documents/10227/18115/Safety+in+Sport++Guidance+for+UK+ National+Governing+Bodies.pdf.

Griffin, M.A. .2002. Safety climate and safety related behavior. Australian Journal of Management 27(1) Special Edition.

Halimaton Hamdan \& Zaiton Abdul Majid.2014. Laboratories Safety. Kuala Lumpur: Dewan Bahasa \& Pustaka.

Halpin, A.W. \& Croft, D.B. 2013. The Organizational Climate of School. Chicago: Midwest Administration Center, University of Chicago.

Lee Lam Thye. 2017. Sekolah patut peka keselamatan warga. Sinar Harian, 15 March 2017.

Meor Ibrahim Bin Kamaruddin \& Nurul Huda Binti Yazit. 2010. Pengetahuan Amalan Keselamatan Makmal Sains Dalam Kalangan Guru Pelatih Sains, Fakulti Pendidikan, Universiti Teknologi Malaysia. Unpublished working paper, Universiti Teknologi Malaysia, Skudai, Johor.

Ministry of Education Malaysia. 2011. Surat Pekeliling Ikhtisas Bil. 8/2011 Pengurusan Keselamatan Murid Di Sekolah.

Mohd Salleh Lebar. 1997. Sosiologi Sekolah dan Pendidikan. Selangor: Thinker's Library.

Mohd Tarmizi Mohd Zabidi. 2007. Kajian terhadap permasalahan yang dihadapi guru guru kemahiran hidup bersepadu dalam penyelenggaraan bengkelsekolah sekolah menegah harian dan sekolah menengah agama di zon sentul, Kuala Lumpur. Unpublished Diss., Universiti Teknologi Malaysia, Skudai, Johor.

Meor Ibrahim Kamaruddin \& Nurul Huda Yazit. 2010. Pengetahuan amalan makmal sains dalam kalangan guru pelatih sains. Unpublished Masters Thesis, Universiti Teknologi Malaysia, Skudai, Johor.

Malaysian Statistic Department. 2013. Annual Reports. Kuala Lumpur: Percetakan Negara,.

Mortimore, T. 2008. Dyslexia-curse or blessings? Dyslexia learning styles. New York: John Wiley \& Sons.

National Education Association Safe School Manual .1996. Model Sekolah Selamat.

Neal, A. \& Griffin, M.A. .1998. Safety climate and safety related behavior: An integrated model. Paper presented at the 24th International Congress of Applied Psychology, San Francisco, California.

Olweus, D. \& Limber, S. 2009. Bullying Prevention Program, in Elliot, D. S. (Ed.), Blueprints for Violence Prevention. Denver: C\&M Press CO.

School Management Division. 2008. Konsep dan Manual Sekolah Selamat. Ministry of Education Malaysia.

School Management Division. 2008. Panduan Pengurusan 3K. Ministry of Education Malaysia. 
School Management Division. 2012. Konsep dan Manual Sekolah Selamat: Panduan Pelaksanaan menjadikan Sekolah, Komuniti dan Keluarga Selamat untuk KanakKanak. Ministry of Education Malaysia.

Shamsiah Mohd Amin \& Said Hamdan .2009. Satu kajian kes terhadap kepuasan guru terhadap sekolah selamat. Unpublished Masters Thesis, Universiti Teknologi Malaysia, Skudai, Johor.

Salleh Buang. 2005. Konsep dan perlaksanaan sekolah selamat. Unpublished working paper, Seminar Pendidikan, Fakulti pendidikan UTM Johor Baharu, 15 October.

Sharifah Md. Nor. 2000. Keberkesanan Sekolah, Satu Perspektif Sosiologi. Serdang: Penerbit Universiti Putra Malaysia.

Tang Hing Kwong .2002. Kepentingan Pengetahuan Dan Kemahiran Tentang Penggunaan Alat Sistem Keselamatan Kebakaran di Makmal Kejuruteraan Awam KUiTTHO. Unpublished Masters Thesis, Kolej Universiti Teknologi Tun Hussein Onn, Johor.

Tie Fatt Hee. 2004. Liabiliti dalam Pengurusan Pendidikan. Kuala Lumpur: Utusan Publication.

Utusan Online (2014), "Pelajar Cedera Jatuh Longkang", 9 February, available at: http://www.utusan.com.my/utusan/Dalam_Negeri/20140209/dn_20/Murid-darjahlima-cedera-jatuh-longkang-di-sekolah.

Utusan Online .2014. Pelajar MRSM Dipanah Petir. Available at http://www.sinarharian.com.my/edisi/melaka-ns/pelajar- mrsm-dipanah-petirmeninggal-dunia-1.26688679.

Uma Sekaran. 2012. Research Methods for Business, A Skill Building Approach (12 ${ }^{\text {th }}$ Ed). India: John Wiley.

Xiao Lini \& Ma Yingnan. 2010. Study on safe school building based on current situation and long effect mechanism. Proceeding of International Conference on Emergency Management and Management Science, Beijing 8-10 August .

Yusof Boon \& Jamaluddin Ramli. 2008. Remaja dan Tingkah Laku Agresif. Skudai, Johor: Penerbit Universiti Teknologi Malaysia. 